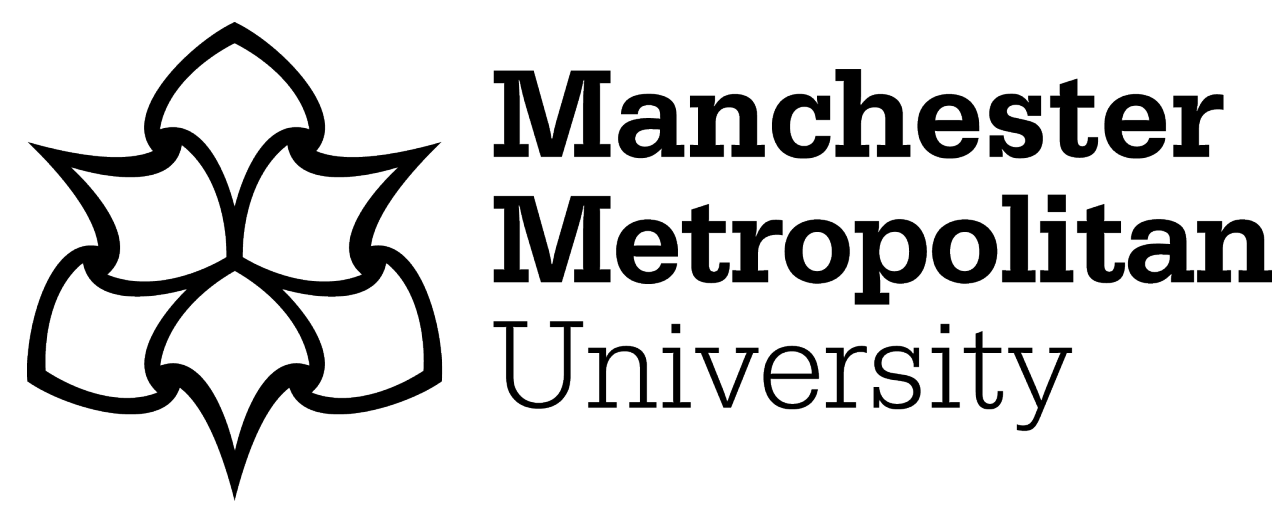

Cavalcanti-Bandos, MF, Quispe-Prieto, S, Paucar-Caceres, A ORCID IogoORCID: https://orcid.org/0000-0002-4690-561X, Burrowes-Cromwel, T and Rojas-Jiménez, HH (2021) Provision of education for sustainability development and sustainability literacy in business programs in three higher education institutions in Brazil, Colombia and Peru. International Journal of Sustainability in Higher Education, 22 (5). pp. 1055-1086. ISSN 1467-6370

Downloaded from: https://e-space.mmu.ac.uk/628488/

Version: Accepted Version

Publisher: Emerald

DOI: https://doi.org/10.1108/IJSHE-07-2020-0247

Usage rights: Creative Commons: Attribution-Noncommercial 4.0

Please cite the published version 


\title{
Provision of Education for Sustainability Development and Sustainability Literacy in Business Programs in three Higher Education Institutions in Brazil, Colombia and Peru
}

\begin{abstract}
Purpose: This paper reports on the status and the development of Education for Sustainable Development (ESD) and sustainability literacy (SL) in three Latin American (LA) Higher Education Institutions (HEIs) business programs in Peru, Brazil and Colombia. The paper examines institutional efforts to both introduce and to implement ESD curricula and provide sustainability literacy.

Design/methodology/approach. The methods used in this paper included reviews of university webpages and course materials. Structured interviews were also conducted with program leaders, in order to examine the level of ESD, as an input affecting the business programmes curricula of the universities concerned.

Findings. Initial findings suggest that, in the three HEIs surveyed, there is still a tendency to talk about issues related to ESD but actions that confirm this interest are not sufficiently advanced. We surveyed a sample of business programmes curricula and interviewed its leaders and a mixed and dated picture emerged. When compared to other regions particularly the US and Europe, our findings show that the HEIs surveyed still have not developed enough work to distinguish conceptually between sustainable development, ESD, and sustainability literacy making the embedment of these concepts in the curriculum not fully developed.

Originality/value: In Latin American HEIs, the ESD message seems to be slowly taking ground, equipping HEIs to respond to sustainability literacy concerns. Implementation and practice in some HEIs are still at an embryonic and conceptually confused stage with regards to Latin American HEIs sustainability literacy. This paper sheds light to help ESD delivery. It offers some strategies for moving on from this inception phase to a more structured sustainability literacy provision and ESD outlook.
\end{abstract}

Keywords: Business Programmes, Sustainability Literacy, Education for Sustainable Development, Green Economy, Climate Change 


\section{Introduction}

The Covid-19 pandemic has completely destabilized the global economy. It has exacerbated already existing inequalities, with dire consequences for human suffering. The pandemic has been an unparalleled wake-up call that has exposed the shortcomings in the 2030 Agenda for Sustainable Development and the Paris Agreement on climate change. It has further prompted UN (United Nations) urgency about addressing these problems regarding climate change and sustainability. In the words of UN Secretary-General António Guterres:

'We need to turn the recovery into a real opportunity to do things right for the future.' (United Nations, 2021a)

Over the last decade, HEIs (Higher Education Institutions) have played an important role in raising awareness about climate change. The United Nations has signalled the role of education and the importance of HEIs in achieving the UN sustainable development goals (SDGs) as well as the 2030 Development Agenda. There are some signs that heads of universities, other HEI staff (both academic and administrative), students and other stakeholders are driving the processes towards a more sustainable present and future (IAU, 2019). Public awareness and attention to sustainability education or education for sustainable development (ESD) ${ }^{1}$ are also spreading worldwide and, in some ways, higher education institutions (HEIs) are leading this "green" awareness movement (Weissman, 2012).

While efforts to increase awareness of the sustainability agenda seem to be progressing at a good pace among American and European universities, the situation in Latin America is not as promising. As some commentators have indicated, examples of ESD integration into curricula and academic literature are heavily biased towards European and North American perspectives. There is a clear absence of documentation which focusses on Latin America contexts (Blanco-

\footnotetext{
${ }^{1}$ Defined by UNESCO as: "Education for Sustainable Development (ESD) empowers learners of all ages with the knowledge, skills, values and attitudes to address the interconnected global challenges we are facing, including climate change, environmental degradation, loss of biodiversity, poverty and inequality. Learning must prepare students and learners of all ages to find solutions for the challenges of today and the future. Education should be transformative and allow us to make informed decisions and take individual and collective action to change our societies and care for the planet. Education for Sustainable Development is recognized as an integral element of Sustainable Development Goal (SDG) 4 on quality education and a key enabler of all other SDGs(link is external). As the lead UN agency on ESD, UNESCO is responsible for the coordination of the ESD for 2030 Framework. https://en.unesco.org/themes/education-sustainable-development
} 
Portela et al., 2018; Hernández-Diaz et al., 2021; Hernandez et al., 2018; Leal Filho et al., 2018; Malheiros, 2019; Salvia and Brandli, 2021) . A cursory review of Latin American HEIs indicates that these organizations have had rather slow uptake of sustainable development in their teaching and research agendas- particularly in a comprehensive way.

Bearing in mind the climate challenges to vast areas of the Latin American continent, the urgency behind ESD is timely. There is a pressing need to encourage Latin-American HEIs to take up a more active role in bringing about change. This is especially true when considering that the region has three large countries (Brazil, Colombia and Peru) with the highest biodiversity in the world. This paper aims to address that gap by alerting HEIs to grasp the opportunity to spread the SD message by establishing sustainability literacy in their curricula. The intention is not only to encourage preservation and conservation initiatives but also to promote inclusion of sustainable development in the HEI curriculum of these three countries.

Among its many measures to address global challenges, the $\mathrm{UN}$ is emphasising this need to integrate sustainable development at all levels of education. Agenda 21, Chapter 36 outlines this (United Nations, 2019). The concept was originally refined at the International Conference on Environment and Society which was held in Thessaloniki - Greece in 1997 (UNESCO, 1997). The main idea behind both of these events was that education should be re-oriented towards sustainable development. This could be a strategic conduit for changing societal thinking, attitudes and behaviours. UNESCO is now admitting that the prevailing knowledge paradigm fails to provide solutions to global challenges (UNESCO, 2017). Thus, through ESD, the intention is to enhance student competencies such as: critical thinking, imagining and forecasting future scenarios, especially as they relate to sustainability. This change process also includes working collaboratively to respond appropriately (UNESCO, 2017). For the purposes of this paper, Education for Sustainable Development (ESD), or sustainability literacy, will be defined as the knowledge and skills 'needed to work and live in a way that safeguards environmental, social and economic wellbeing, both in the present and for future generations'(QAA, 2014). The ESD concept has several meanings and interpretations. UNESCO defines its pillars, but the authors found the QAA construct cited here as more suitable for the purposes of this paper and the special issue's theme of sustainability literacy.

The notion of sustainability and its implications span three broad facets of human existence: the social, environmental, and economic. Using accounting terminology, these elements also 
provide a way of evaluating sustainability according to a "triple bottom line" of: social, environmental, and economic responsibility (Elkington, 1999). It follows that sustainability, sustainability literacy, and sustainable development are essentially interdisciplinary study areas. Moreover, by using the lenses of this triple bottom line, we are able to actually examine their point of intersection. In this research (and in laying out our findings) we lean more to the overlap defining the environmental and economic features that are relevant to the HEI role.

It is worth noting however, that this is not to negate important arguments about the social aspect. For example, with reference to HEIs, we argue that this would begin by first valuing the university as an inherently social institution. This is because of its fundamental mandate for training students in higher learning. A university is also a type of 'community' and, other related points are developed further on in the paper.

We should also note the social dimension of SD in current messaging about human behavioural change as critical for securing SD outcomes (Atherton, 2019). Furthermore, a vibrant discussion is now taking place about the importance of collaboration in the SD paradigm (Becker and Smith, 2018; Colurcio and Russo-Spena, 2013; Kraaijenhagen, van Oppen, and Bocken, 2016). Arguably, responding to these conversations could demand a management spectrum of change (individual to organizational) within business settings, and of course, these include HEI administration and programming.

Against this backdrop, the concept of sustainability, (and thus, providing students with sustainability literacy), poses considerable difficulties as a subject to be conveyed in HEI curricula. This is because it is both an integrative discipline and a multidisciplinary endeavour for transforming problem areas. In order to be fully embraced and embedded, this requires some understanding of both hard and soft data, as well as using scientific and more interpretivist approaches to bringing about change. This paper draws from relevant ESD theory in revisiting the above debates. It assesses the situation of HEIs in the Latin-American context. In order to achieve this, we have concentrated on three universities that provide business education at an undergraduate level.

The general aim of the paper is therefore to study the development of Education for Sustainable Development (ESD) and overall sustainability literacy in university business programs in Latin 
America. Using case studies from three HEIs in Brazil, Colombia and Peru, we address the following research questions:

RQ1: What were/are the ESD policies in Business Education (BS) being implemented in HEI, in other regions of the world? A search in the relevant literature will help to answer this question.

RQ2: What is the state of the ESD in Business Education in Latin America? Similarly, we expect to use the literature reviewed, backed up by analysis of relevant documents and some interviews.

RQ3: What are the university policies to encourage SD in Business Education in these three universities? This question will be answered mainly through a set of structured interviews with business program leaders.

RQ4: What are the main themes of the SD-oriented curriculum being implemented in the three universities studied? Analysis of documents and the results of the interviews will help to answer this question.

RQ5: Are there any lessons to learn (compare) across the three universities in this sample to improve ESD in business programs in LA. Similarly, we hope to arrive at relevant conclusions after the analysis of documents and the results of the interviews will help to answer this question.

The paper is structured as follows. After the introduction, in Section 2, we discuss the literature about integrating Education for Sustainable Development into university curricula. We tried to link the key concepts of SD as part of the UN agenda and, connect these with developments in the three countries under study. We finish this Section with a survey of the Brazilian, Colombian and Peruvian HEIs offering related sustainable development courses and campus initiatives.

In Section 3, we introduce the conceptual framework and the research questions driving our study. In Section 4, we outline the methodology, explaining in detail the document analysis and the interviews with business programs leaders in the three universities. In Section 5, we 
report the results of the two stages of our empirical research viewing the discussion through the lenses of the well-known triple elements defining sustainability and delivery of the SDGs. Conclusions and suggested themes for further research are proposed in Section 6.

\section{Literature Review: Sustainable Development and Education for Sustainability in Higher Education Institutions in Brazil, Colombia and Peru.}

The literature on ESD lays out a number of positions. As noted earlier, in this paper, we focus only on two strands for the purposes of centring our discussion. In the first one, we discuss Education for Sustainable Development in higher education institutions and examine their role within the framework of SDG implementation. This is followed up by an extended discussion about ESD business programming in higher education institutions. In each if the sections, we start by discussing the general context. Then we describe levels of progress in the Latin American countries, namely: Brazil, Colombia and Peru. In the following sections, we outline the development of Sustainable Development and Education for Sustainability in Higher Education Institutions in these countries.

\subsection{Education for Sustainable Development in HEI in Colombia, Brazil and Peru}

The global thrust for Education for Sustainable Development (ESD) in higher education institutions (HEIs) became more evident after 2015, when world leaders adopted a set of targets to eradicate poverty and to protect the planet. During this time, many countries reached agreements to implement sustainable development university policies in the three dimensions: economic, social and environmental. Albareda Tiana et al. (2017, p.253.) explain that "changes have been introduced in the implementation and promotion of sustainability, especially in the economic and environmental dimension in many universities, but less progress has been made in the social dimension and in the integration of all of them [...] there are still many gaps in the curriculum". At this point, we re-connect with our earlier comments about the social aspect of the 'triple bottom line'. We hold the view that universities are first and foremost social institutions with an important role in transforming society (Castillo-Cabeza et al., 2016). Thus, from the start, the teaching, training and research functions of HEIs represent a substantial contribution to civic development. This is undoubtedly a very influential position for achieving any national transition towards sustainability. 
In other words, the HEI is not only a space for professional advancement but for maturing responsible citizenship (Bronzeri and Cunha, 2020). Apart from supporting research knowledge and exchange, HEIs have already been taking up the challenge to realize this by introducing sustainable development as part of their institutional profiles and activities. The latter specifically includes developing teaching methods to implement Education for Sustainable Development (ESD) (García-González et al., 2017). The objective here is to prepare students as catalysts, among others, with communal responsibility for sustainable development (Lozano et al., 2013; Vargas et al., 2019). Overall, in the last decades, Sustainability, Sustainable Development and Education for Sustainable Development are increasingly central concepts, both in social practice and in the field of scientific knowledge. (Serpa and Sá, 2018; Décamps et al, 2017 ; Carteron et al, 2014; Kieu, Fernandez and Shaw, 2016).

When it comes to Latin American development gains, the Economic Commission for Latin America and the Caribbean (ECLAC) notes (before the pandemic) significant advances in areas such as health and education. There has also been improved access to: housing, basic services such as drinking water, electricity and sanitation and to the internet. (CEPAL, 2016). Yet, gaps still exist in terms of capacity to employ comprehensive strategies at university level. ESD is necessarily transdisciplinary (Alves, 2017) but there are significant hurdles (Albareda Tiana et al., 2017). These entail (but are not limited to) integrative curricula design and more effective joined up working. The latter point is not limited to cross-faculty cooperation but also research investigation. HEIs now have good opportunity to take a more engaged scholarship approach to the 'real world' (Van de Ven, 2007). Within the framework of ESD, this implies some measure of committed interaction with policy makers, business actors, community and other external stakeholders.

Facilitating lasting pathways for humanity at the international level is no mean task and as noted above, some universities have already confirmed their commitment to this transition (Vargas et al., 2019). The Green European Pact (adopted at the end of 2019) has been working along these lines to define supportive roles. In the drive to revamp the European Union as a sustainable economy, universities are definitely included among many stakeholders. Apart from teaching, the 'value-added' roles of HEIs include research and innovation. This would also entail disseminating information, strengthening capacities and helping to change attitudes 
regarding climate change and sustainable development (Fernandez, 2020). La REDS stands out as one good example in this regard. It is a Spanish network for sustainable development that is a launching pad for universities to start promoting SDGs. La REDS is therefore able to function as a repository of information by providing access to the contributions of HEIs working in the field. Hidalgo et al., (2020) argue that La REDS has significantly enhanced the role of universities in achieving some SDGs (Hidalgo et al., 2020).

As far as Latin America is concerned, there are a number of networks that have been created to promote mainly university social responsibility and there is some hint of promoting ESD awareness in their ethos. An example of these efforts are the actions of the network URSULA (In Spanish: Unión de Responsabilidad Social Universitaria LAtinoamericana). (Union of Latin American University Social Responsibility. This network, was created by the Directorate of Social Innovation of the CAF Development Bank of Latin America, and has hundreds of dedicated Higher Education Institutions (IES) (URSULA, 2020). It promotes a new model of 'being and doing university'. It views the HEI as an integral entity, with a posture towards academic and institutional quality that is responsible, fair and, seeks the sustainable evolution of science, professions and teaching, in the service of society. Thus, it promotes the exchange of concepts, experiences and, models of sustainable integral management of University Social Responsibility (USR). This approach includes an essential model for the transformation of higher education comprising: social participation, organizational management, cognition and training. Furthermore, curriculum inclusion of the SDGs and the sustainable campus are among the working goals. In the last decade of the 21 st century, a large number of universities have adopted this approach, not only in Latin America but also in Spain. In addition to the above, there are also two networks with similar objectives: Red RSU de la Organización de Universidades Católicas de América Latina y el Caribe (ODUCAL, 2020) and Observatorio Regional Social para América Latina y el Caribe (Unión de Responsabilidad Social Universitaria Latinoamericana, 2020)

\subsubsection{Brazil}

When examining the status of ESD among the Brazilian HEIs, Leal Filho et al. (2018) build on this point about an integrative approach. Likewise, Shiel et al. (2016) and Trencher et al.(2014) support the view that universities should develop a systemic approach to sustainable development - leading through research, education and community engagement interventions that are decisive for the survival of the Planet and all of humanity. In 2015, Brandli et al., 2015 
highlighted barriers and preconditions to crafting a sustainability matrix for Brazilian universities. These researchers concluded that the HEIs should realize their significant ESD role in the society by: educating leaders, advancing knowledge to bolster organizational development, support culture and plan for sustainability integration (Brandli et al., 2015).

A more recent update from the Superintendent of Environmental Management at the University of São Paulo bemoans that whereas some Brazilian universities are becoming aware of environmental sustainability, others have been thinking about it for more than 25 years. (Malheiros, 2019). Yet, there is definite progress as Brazilian universities are including SD features in their research, teaching, and outreach activities. They are also paying attention to social and environmental issues in their planning and management processes (Malheiros, 2019).

In 2018, after the seminar entitled; II National Workshop on UI Green Metric for Universities in Brazil - 2018" (organized by the University of São Paulo), the Sustainable Universities Network was created with actions and interests surrounding the theme of sustainability. Its primary aim was to exchange knowledge of good practice. According to them HEIs are educating young people in an environmental awareness. All praxis should be rooted in the understanding that HEIs must have an integrating system that minimizes the socioenvironmental impact of their own activities. For example, projects may include: solid waste management, energy management, care for green areas and their biodiversity, alignment with SDGs involving the academic community and society. The academic activities should provide environmental education and, the formation of critical thinking surrounding rational bases for exploring the environment but with long term implications in mind. The Network's efforts eventually led to a publication outlining the experiences and challenges regarding strengthening academic cooperation among Higher Education Institutions in Brazil (Malheiros, 2019). In response to all this, Leal Filho et al. (2018) concludes that although more universities in Brazil have stepped up with progressing their sustainable development agendas, most really have only one initiative as proof of action. (Leal Filho et al., 2018).

\subsubsection{Colombia}

Since 1994, there was a move for more environmentally aware teaching at all levels of formal education, in Colombia, including the HEIs. However, it was only in 2003 that an 
Environmental Education policy was formulated. In 2012, The National Environment Educational Policy (the Law 1549) was launched, which catered to territorial development. (Rojas and Pineda, 2016). Additionally, Higher Education for Sustainable Development is being significantly shaped by the global sustainability agenda. In this way, universities are taking responsibility for equipping the next generation of sustainability leaders with essential knowledge and skills. This entails proactively addressing sustainable development goals (SDGs) in Higher Education for Sustainable Development policy and also, through various initiatives aimed at curriculum and practice. In this context, Environmental Education is becoming a more complex model, where several environmental, social and economic factors are taken into account. (Acosta, et al. 2020; O'Brien, 1995; Hernández-Diaz et al. 2021).

Rojas and Pineda (2016) also explained that this policy is criticized because the educational institutions focused only on complying with regulatory requirements. Although, lecturers went even further by using an operational approach, providing information about how to improve practices and disseminated it, more practical actions are needed. Flórez-Yepes (2015) also makes the point that environmental education and sustainable development must constitute some comprehensive teaching and learning direction. The point here is that this should include basic training, supported by values and principles but above all, it should be couched in an ethical framework.

At the same time, Ortegon and Acosta (2019) assure readers that Colombian HEIs have been proactive in response to social responsibilities. These measures encompass social inequality and uneven access to higher education. Yet, in their opinion, the implementation of any type of holistic green initiative in HEIs is still scarce in Colombia. It is not surprising therefore that sustainability literacy is not yet embedded in Colombian HEIs. This is despite the fact that some strategies have been devised to promote the integrity of environmental education through projects such as: ecological walks, cleaning of river basins, workshops in wetlands, learning about the 3Rs, development of skills in circular production and clean production, among others. We may conclude that overall, although Colombia has advanced in meeting some areas of environmental education, in many instances sustainability literacy is currently lacking in most of Colombia's current HEIs. Generally, there is local support in some HEIs towards environment-only issues at the local level. This has taken the form of an activist stance and even while achieving some concrete action, it is often without major impact. (Flórez-Yepes, 2015). 


\subsubsection{Peru}

Higher Education in countries like Peru, lacks a system of political frameworks for implementing sustainable development in HEI education programmes (Hernandez et al., 2018). Despite this, promoting actions for sustainable development is increasingly a priority within the education sector (Shephard, 2008) and some efforts are gaining ground at Peruvian universities. One example of this is a group formed by 75 universities which is entitled; the Inter-university Environmental Network. This Association is committed to fulfilling 37 sustainability indicators pertaining to: environmental governance, educational proposal, research, internal environmental management, and social community engagement (Proyeccion Social) (Universia, 2019).

Other universities promote the scope of the 17 SDGs, as well as host meetings to evaluate them. For example, one consortium of four Lima universities shared research findings about the most important challenges still remaining to meeting the SDGs. As a result of the inter-institutional, inter-university and multidisciplinary investigations generated, they devised a way for mapping the real case scenarios of Peruvian communities in their efforts to meet the SDGs (Consorcio de Universidades, 2016).

It is worth mentioning that lately there have been some efforts to increase awareness of both social responsibility and sustainability matters in Peru. Among examples are the activities of the Red Internacional Universitaria de Responsabilidad Social y Ambiental (RIURSA)/ International University Network for Social and Environmental Responsibility. This working space integrates the participation of national and international universities, in order to strengthen a culture of university social and environmental responsibility, towards sustainable development. It is chaired by the Universidad Nacional de San Marcos and has been very active in promoting social responsibility and sustainable development amongst the universities in the network. Universidad Nacional Jorge Basadre Grohmann (2020)

\subsection{Education for Sustainable Development and Education for Sustainability in Business Programs in the Latin American Region}

Including ESD in business programs is a relatively contemporary strategy which is still being worked out at national and international levels. However, discussion about this has been 
unfolding since the 2000s (Hidalgo et al., 2020) with Business Administration as one of the obvious career pathways for business programs at the HEI level. In this case, Business Administration requires that the graduate has the requisite technical and general knowledge and the ability to employ appropriate skills and competencies to successfully manage a business. It is important that this learning process includes well-rounded viewpoints on a given subject, with environmental awareness added to this profile. (Petarnella et al., 2017).

The task facing sustainability literacy in HEI business programs is the challenge of training managers and leaders with understanding about how organizational decision-making and management may impact a sustainability agenda (Yamamoto et al., 2020). As a result of this, some suggest the need for a teaching approach which utilizes pedagogical, didactic methods, especially with reference to the messy scenarios of everyday living. These may include: simulations, case studies and problem-solving techniques among others and, above all, tutor engagement is essential. (Godoy et al., 2013). Others point out that very little has been done to undergird the theme in undergraduate courses, although there may be incremental advances in positioning the issue of sustainability in management courses (Franco et al., 2017; Jacobi et al., 2011). Whatever the case, universities must be poised to train future professionals and researchers to meet the sustainability challenges of this century. This will mean generating institutional alertness and critical awareness, so that humans are able to flourish within a sound, sustainable environment (Minguet Aznar et al., 2014).

Still on the subject of business programs, it is worth mentioning the Principles for Responsible Executive Education (PRME) initiative which was launched by the UN in 2007. Specifically, its mission is to:

[...] transform management education and develop the responsible decisionmakers of tomorrow to advance sustainable development. PRME works closely with UN Global Compact to have management schools and business collaborate on common aspirations and create collective impact. (PRME, 2021a)

As a global platform of voluntary engagement for business schools and other higher education institutions, PRME hails over 800 signatories worldwide. It is divided into 14 Chapters, with the signatories expressing commitment to integrating universal values in the curriculum and, to research which builds prosperous and successful societies (PRME, 2021a). PRME was meant to raise the profile of sustainability and to equip students with values and standards, through innovative curricula and interdisciplinary collaboration. 
Brazil is the only country with the level of mobilization allowing Chapter representation at the international governance level. This is due to Brazil's geographic configuration, and its vibrant network, which started in 2013, with 27 signatories. (PMRE - Chapter Brazil, 2021). Colombia and Peru are part of the Latin American and Caribbean Chapter. With respect to these two countries; Colombia boasts 24 signatories and Peru has 11 signatories. (PRME, 2021b)

\subsubsection{Brazil}

In Brazil, a document approved by the National Education Council in 2012 states that environmental education is an integral, essential and permanent component for national development. The document stipulates that it should therefore be brought on board at all levels and modalities of basic education and higher education. This is with the intention that educational institutions must integrate it into their pedagogical projects. (Petarnella et al., 2017).

It is interesting to note that since 1997 (as a result of environmental issues in HEI being discussed), the Higher Education Secretariat invited business programs to craft green proposals. These would provide guidance for students about respecting the environment. They would also help to establish environmental strategies and to develop environmental education, within an organizational context. (Petarnella et al., 2017)

According to the curricula guidelines for Administration courses established in 2005, undergraduate content must expose students to national and international sustainability issues in their pedagogical projects (Yamamoto et al., 2020). In this regard, innovation for sustainability represents what has recently been termed as a "window of opportunity" for nurturing business leadership (Jacobi et al., 2011).

Furthermore, the role and impact of the University in sustainability and environmental education should be wide reaching in order to address the climate crisis and, promote sustainable development, to ensure environmental literacy for all students. As Salvia and Brandli (2021) explained (parallel to the development of the 2030 Agenda), the "Universities SDG Network" (a Brazilian Network) was created in 2017 with the objective to strengthen teaching, research and outreach activities (involving the United Nations and HEIs) and, to promote sustainable development in line with the SDGs. However, despite these actions, there is still a lot to be done in this regard amongst Brazilian universities 


\subsubsection{Colombia}

The business administration programs in Colombia are beginning to meet the demands of globalization. Existing association between companies and responsible production were established during the early days. Eventually, sustainability related concepts began to be considered and universities incorporated the topic in their study areas. ESD in business administration programs takes into account the contribution of: the business world, the productive sector, the university, organizations and associations, public sector agencies. Its scope even extends to a participatory role for these institutions in the design, development and evaluation around the notion of sustainability itself (Rendón López et al., 2018). In Colombia, environmental education, in the HEI, has been a re-current theme within the curriculum of each program. However, it is important to study the impact that the inclusion of these subjects has had within the academic curriculum. Such impact allows for strengthening the processes or making structural changes to guarantee that this issue is addressed, transversely to the academic process. Meanwhile, the need for more integrated training can also be tackled (Flórez-Yepes, 2015).

As already suggested earlier in this paper, this requires a dimension of knowledge and tests for solving real problems, involving real social, natural and cultural situations, by deploying investigative techniques and means consistent with higher education (Rendón López et al., 2018). To date, many of Colombia's business administration programs do not provide such pedagogical techniques.

\subsubsection{Peru}

A study in Peru, in terms of sustainability and business reactivation, presented as results that $76 \%$ of companies increased their interest in sustainability. This exceeds the regional average of $70.8 \%$ (PUCP, 2021). Likewise, business models are changing and the demand on the responsibility of universities to forge leaders of the future with integrity, ethical sensibility and social sensitivity, is becoming more urgent in Peru. In this framework, socio-environmental responsibility is highlighted and included within the professional training curriculum. This is in order to ensure that future professionals with a scientific, technological and humanistic base have skills in solving socio-environmental problems. The Government has made great efforts 
to encourage and to address these problems from the classroom. (Ministry of the Environment, 2014).

Moreover, Micaela Patrón explains that the SDGs are really the new metrics that State, companies and society (including HEIs), must take into account (El Comercio, 2020). This suggests that the message of sustainability cannot be excluded from the skillset and training of administrators. This is in order to enrich the university as a community but also, in its interactions with the wider community (Minguet Aznar et al., 2014).

Additionally, (and in line with the above concerns about the development of socioenvironmental economic, educational and societal impact), a study was conducted in Peruvian HEIs on actions aimed at promoting awareness or habitual environmental behaviour in their students. It revealed a "medium to low" level of development, which shows insufficient actions and that strategic plans are urgently needed (Hérnandez, 2021). In another national study conducted with business and engineering students in Peru, the frequency of environmentally friendly behaviours was evaluated and categorized. As a result, one in four students exhibited habitual behaviours and attitudes towards the environment. This is consistent with national levels. Other studies conclude that students with the best academic profiles are also well versed in environmental issues. (Álvarez-Risco, 2018). Overall, this indicates that in Peru the approach follows an environmental paradigm but it is a bit far from an approach oriented to the sustainability literacy structure.

In summary, in the three Latin America countries studied, the ESD connection with the SDGs began in 2015, when the 17 SDGs were agreed at the UN Sustainable Development Summit and this placed HEIs in a prominent role. This opened up avenues for reflection and training, to encourage and to support sustainable actions that transform the world and its citizens. As a region, Latin America has a diverse ecological environment. There are also social inequalities, poverty and other serious problems to overcome. It makes sense to assume that implementing ESD through HEI is even more relevant and, that universities can be institutional catalysts for maximizing sustainability outputs and aspirations. Put succinctly, business courses for business careers must now embrace the ESD agenda. An integrated approach would at least ensure that future company managers are able to make their decisions from a systemic perspective. Our preliminary research and experience with professional bodies of business administration in Brazil, Colombia, and Peru suggest that this shift to ESD has not yet occurred, as many HEIs still focus only on the environmental leg of activity. 


\section{Conceptual Framework}

The conceptual foundations for this article are based on linkages across the three elements, as depicted in Figure 1. The literature review supported the two conceptual elements underpinning this paper. It examined: (1) ESD policies in HEI business education, implemented globally and in Latin America; (2) ESD in business education in Latin America. The methodological strategy allowed development of two structured activities (Activities 1 and 2 in the diagram) for meeting the paper's three objectives. These objectives were directed by the five research questions noted earlier. These objectives shown in Figure 1 are:

(1) Describe the state of the ESD in business education in Latin America;

(2) Identify main themes of the SD-oriented curriculum being implemented in the three universities studied and;

(3) Draw lessons to be learned/ compared among this sample of three universities, in order to improve the delivery of ESD in business programs.

Finding out the state of ESD in business education in the three universities meant screening via the UN grid of 17 SDGs, grouped in five pillars - Five P's: People, Planet, Prosperity, Peace and Partnerships, and they are going to be defined in 4.1. It was also assessed by the wellknown triple bottom line, which intersects at: economic, social and environmental coordinates. This is displayed at the bottom right-hand side in Figure1. 


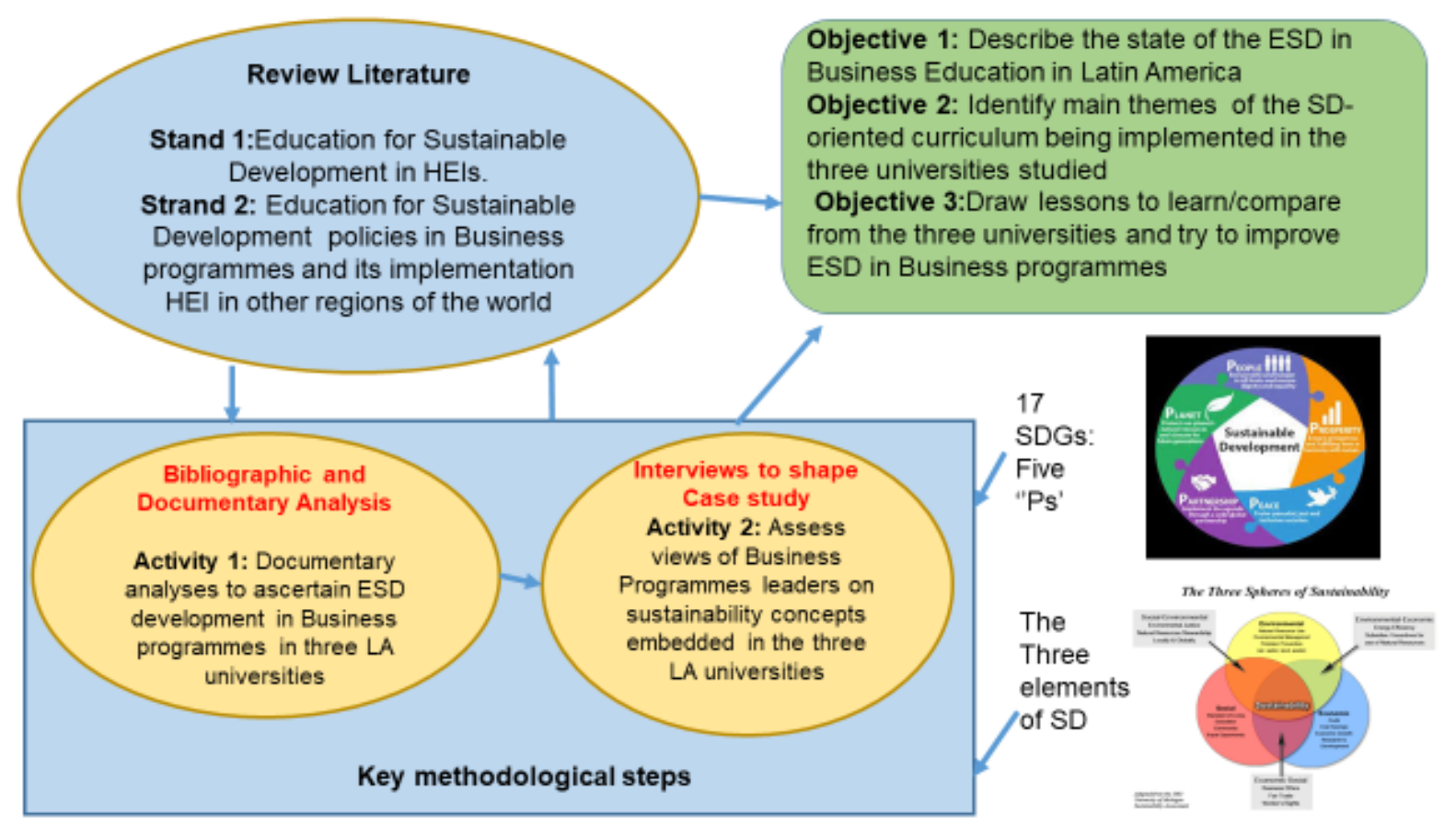

Fig. 1. The conceptual framework of the research

\section{Methodological Overview}

We used a mix-methodological approach to carry out an exploratory study that involved two epistemological strategies: (1) a bibliographic and documentary review and; (2) the case study exploration- via a set of structured interviews. The methodology was applied during the months of January and February 2021 in the business and related programs of the three Latin American Universities in Brazil, Peru and Colombia. Although we are conscious that this is a convenience sample, one can argue that it is a fair representation of what is happening in Latin American HEIs regarding ESD. Course leaders from the three universities responsible for the aforementioned programs approved this study.

The methodology included two activities that put the above-mentioned research strategy into operation. Both activities were developed through the different stages. As can be seen in Figure 1, Activity 1 represents the first methodological strategy. This was a bibliographic and documentary review. Activity 2, comprised interviews with the business program managers and leaders to frame the case study. 
The sample population came from three Latin American universities and four business and related programs. In the University of Brazil, the program for professional careers through Business Administration training was selected. In Peru, two programs were called; Professional Careers in Administrative Sciences and Professional Careers in Commercial Engineering. In Colombia, one program was simply entitled; Business Administration. Directors or program leaders were previously informed of the study objectives. As a result, they gave their consent, and supported the research by providing information on their respective deliveries.

\subsection{Detailed Methodological Strategy}

The research data was supported by two methodological strategies of applied research: (1) bibliographic and documentary review and; (2) Case study of the cases sub-type, with a focus on descriptions. The two steps underpinning the methodology were:

\section{Step 1: The Bibliographic and Documentary Review}

Following this step, information was collected and organized and analysed, taking into account the objectives set forth in this study as depicted in Figure 1. In order to conduct the documentary and bibliographical search in matters related to ESD, we adhered to the four stages and guidelines suggested by Gómez-Luna et al. (2014).

Stage 1: Determine the research questions: The research questions proposed in the previous section were chosen based on the original review questions that guided the parameters of the search.

Stage 2: Information sources: A search for information involved collecting and appraising sources from various online databases, between January and February 2021. In the review, a wide range of materials were compiled. These included standards, technical reports, and reports of state political commissions, specialized magazines, and university web pages.

The search allowed access to the sustainable development policies proposed or implemented in the countries under study, amongst the three universities and business programs. Published research about sustainable development in universities was also reviewed and an online search of the study plans of the different programs was conducted. 
The search for information used the keywords: sustainable development (SD) and sustainable development goals (SDG), business education, the search equations being:

DS and Brazil; DS and Colombia, EDS and Peru; sustainable development and University; ODS implementation and university; sustainable development and business and administration programs

Stage 3: Organization of the Information- The information collected and selected was organized in response to the questions posed, in the following order:

-Education policies for sustainable development in Latin America and then, in the 3 countries (Brazil, Peru, Colombia);

-Education policies for sustainable development in business programs and their implementation in HEIs, the state of business education in Latin America; and

-The main topics of the SD-oriented curriculum that is being implemented in the three universities studied.

Stage 4: Information analysis. At this stage, the organization of the information was analysed and presented in response to the research questions.

Step 2: Case study of the sub-type cases focused on the study of descriptions.

It was decided to use the guidelines for this methodological research strategy, as suggested by the work of Ramirez-Sánchez et al. (2019). Following these guidelines allowed us to respond and to develop Activity 2 provided for in the conceptual framework (at Figure 1). Employing this strategy, in the context of this study was important in that it allowed us to know and to compare the realities of the study countries, through the following phases:

\section{The Preliminary Phase}

This entailed the information search which focused on the universities and the different business programs. By necessity, it meant searching the websites of the respective universities. Their undergraduate programs were accessed to locate curricula plans and this included detailed syllabus and semester searches. 


\section{The Phase of expression of opinions, impressions and judgments}

In this stage, courses were selected using names of the units/ subjects that bear the explicit term sustainable development or the acronym EDS. Likewise, the courses with contents, competencies or subjects related to SD were considered in relation to the three SD elements and the SDGs themselves (as depicted in Figure 1).

Once the courses had been selected, the information was displayed on a spreadsheet that contained the number of courses oriented to ESD, the number of courses with SD topics, area of study, the semester in which it is taught, credits and, theoretical and practical hours. (See Appendix 1). At the institutional level, the mission of the University and the program was assessed and opinions on the matter were noted.

\section{The Phase of comparing and contrasting}

In this Phase, a structured interview was carried out. The project team designed a set of 10 questions; the questions were piloted amongst some colleagues from the three universities before using them. The final questionnaire comprised 10 questions and was directed to the leaders responsible for conducting the business and related programs at the three universities. The questionnaire was drafted in Spanish and Portuguese. Answers were collected in the original language (Spanish for Peru and Colombia) and Portuguese (Brazil) and then subsequently translated into English. (See Appendix 2 for the English Version).

Program leaders provided a description of the implementation of subjects or courses within the plan of studies that are being developed. They also noted the particular topics of emphasis and the results that they present during the implementation of the same (that allowed contrasting and comparing the information collected).

In order to discuss the results of the interviews, we took into account the extent the content and the way subjects reported were inserted in the programs, as well as how this helped to consolidate Education for Sustainable Development (ESD). ESD was defined according to the well-known triad to balance and to create the knowledge and skills '. . .needed to work and live in a way that safeguards environmental, social and economic wellbeing, both in the present and for future generations', as suggested by (Hernandez et al., 2018). 


\section{The Theoretical Reflection Phase}

This Phase was developed by analysing the implementation of sustainable development segments within each business and related program; making a comparison among the universities of the countries under study. Once again, it was based on the three-dimensional model: environmental, economic and social. This reflection exercise was enhanced by taking into account the messaging in the 17 UN SDGs (United Nations, 2021, b). Therefore, in order to better examine the importance of the UN message, the SDGs may be categorized according to the five Ps: People, Planet, Prosperity, Peace and Partnerships. (Fundación Aquae, 2013)

- People: aims to end poverty and hunger, in all their dimensions and manifestations and, to ensure that all human beings can fulfil their potential in dignity, with equality and, while thriving in a healthy environment.

- Planet: aims to protect the planet from degradation, including through sustainable consumption and production, sustainably managing its natural resources and, taking urgent action on climate change. This is so that the earth can support the needs of the present and future generations.

- Prosperity: aims to ensure that all human beings can enjoy prosperous and fulfilling lives and that economic, social and technological progress occurs in harmony with nature.

- Peace: aims to foster peaceful, just and inclusive societies, which are free from fear and violence. There can be no sustainable development without peace and no peace without sustainable development.

- Partnership: aims to mobilize the means required to implement this agenda through a revitalised Global Partnership for sustainable development. This is based on a spirit of strengthened global solidarity, focused on the needs of the poorest and most vulnerable and, with the participation of all countries, all stakeholders and all people.

\section{Analysis and discussion of results}

Of the three universities in this study, the universities of Peru and Brazil are public but the one in Colombia is a private university. The average number of undergraduate students in business education programs in the respective schools is 400 students. The universities in both Brazil and Colombia have a business program and the Peruvian university offers two business 
management programs. One of the universities is located in the capital city and the other three in cities in the interior of their respective countries. In the below Section, we report the results of implementing these two activities.

\subsection{Bibliographic and Documentary Analysis: Documentary analyses to ascertain ESD development in business programs in three LA universities.}

\section{Activity 1 of key methodological steps:}

The information was collected using an Excel sheet (See Appendix 3. for the Spanish version used). A summary of the main elements of the search is contained in Appendix 1. Insertion of Subjects in Business Programs and / or Administration of Universities of Brazil, Peru and Colombia. The information that was analysed corresponds to: the overall institutional mission and the undergraduate program, as well as the subjects or subject s) (primarily directly at teaching cognitive, attitudinal and procedural aspects). These are within the framework of the UN SDGs in Agenda 2030. We looked out for explicit occurrences of the term "sustainable development" or for those that have some content related to the SDGs and finally, any sustainability activities that were inherent within universities.

With respect to institutional mission statements that in this first analysis of content identify the inclusion of the term "sustainable development" (as evidence of strategic commitment) - none of the countries explicitly use this term. However, there is other jargon related to the five central elements of the SDGs. For example, these include: "ethics and citizenship"; "promotes and practices absolute respect for life"; "promotes tolerance as a way to achieve peace and progress within heterogeneity". At least, these all meet the aspirations attributed to the social dimension of the triple bottom line.

As mentioned earlier in this paper, university life may be closely aligned to several of the SDGs. Where the university plays a leading role, its contribution may very well embrace each SDG-within its: teaching/learning functions; research; governance framework; management policies and university extension and; social leadership. Again, the argument here is that all HEIs need solid interconnections across the social, economic and environmental dimensions, (as well as the institutional objectives themselves), to meet the SDGs and, to help create a sustainable world. In this way, the institution and its organizational intentions should be regarded and considered as an indivisible whole. (REDS, 2020)(Australia/Pacifi, 2017). 
On this note, the overarching business program missions presented in Appendix 1 confirm inclusion of the term "sustainable development" in the University of Brazil and Colombia. This contrasts with the University of Peru, which does not use this term. However, that institution does reference the term "Social Responsibility" in its official declaration, as does the University of Brazil.

Argentine researchers (Panario, 2021) propose that in recent years, the interlocking theme of business and sustainable development has shown exponential growth in society, academia, and among decision makers. It follows that in training business professionals, it is appropriate to utilize a framework which considers the notion of 'sustainable finance'. In so doing, this would bolster the objectives of Sustainable development within the marketplace. It would provide a context for rebuilding national economies, while requiring that these same companies are transparent about their contributions, committed to evaluating their impact and, addressing any negative results (Ernst \& Young Global, 2015).

Therefore, it can be argued that in training business students, program models should be rooted in sustainability concepts- as well as purporting ethical and moral principles. The aim would be to generate and to manage creative, productive, technical and social proposals that contribute to the development priorities of a particular country. This issue was raised many years ago and is now gaining increasing interest in the academic field of administration (Hidalgo et.al, 2020).

Another aspect that has been considered in the Table in Appendix 1 are the names of the business programs, where the denomination differs in the University of Peru in the two programs that it presents. In relation to the subjects or subjects with a main purpose to teach the SDGs, Brazil presents 1 course; Peru 2 courses and Colombia 3 courses, it should be noted that in the three countries the denominations coincide according to the description: "sustainable development" and "Social Responsibility". Both terms are closely linked to the business field and gain real importance within the institution by fostering future business behaviour based on managing impacts on society (social responsibility), positioned for the long term (sustainability) and being an important agent in improving the quality of life of society (sustainable development) 
According to some researchers, by using the terminology 'Education for Sustainable Development' this means ". . inevitably, speaking of the commendable role that the United Nations has played throughout all these years so that education and sustainability begin to be a reality in all corners of the world" (De la Rosa, Daniel; Giménez, Pilar; De la Calle, 2018). Evaluations are carried out worldwide on progress towards the goals for universities and although the advancement is not always ideal, the fact that this green movement has been influencing the university environment cannot be denied (Albareda Tiana et al., 2017; Leal Filho et al., 2018).

The implementation of sustainability education in business programs is also evident within the themes of the other subjects of the study plan, when the topics are presented in a cross-sectional way. It is worth noticing that the greatest weight falls on the economic dimension by the very nature of the degree, followed by the social dimension and to a lesser extent, environmental management has been addressed. This was confirmed in the information provided by the managers that were interviewed. This is also corroborated by some investigations that show the balances across the three axis (Bugallo-Rodríguez and Vega-Marcote, 2020).

\subsection{Assess views of business program leaders on sustainability concepts embedded in the three LA universities.}

\section{Activity 2 of key methodological steps}

As explained in the methodology section, 10 questions were posed to those responsible for business programs at the researched institutions. Questions and answers are found in the table at Appendix 2. It should be clarified once again that in Peru, two business programs from the same university were analysed, while in Brazil and Colombia, only one was reviewed. Thus, in the column of Appendix 2 that deals with Peru, the first answer refers to the Business Administration program and the second to the Commercial Engineering program.

With respect to the first question, the researchers' objective was to find out the interviewee's interaction time with the Program Director. We found that the oldest manager (who started his post in 2007) is Colombian. In contrast, the Brazilian and Peruvian program leaders are relatively new to the course management, having started in 2017 and 2020, respectively.

We also asked about specific disciplines in the courses that deal with sustainability. The Peruvian curriculum of the first institution questioned and the Colombian institution have the largest number of subjects. This range includes: "Sustainable development and social 
responsibility", "Management of social projects" and: "Ethics and Social Responsibility", in Peru, and "Sustainable development", "Social Responsibility" and "Eco-design", in Colombia. In the Brazilian institution, there is only one disciplinary area called "Strategic Management for Sustainability" and in the second Peruvian institution, one was entitled "Social Responsibility". We were able to verify that the majority of courses were being delivered in the final degree stages and also, they have been on the curricula for more than 10 years. The second Peruvian institution was the inverse to this, as the topics were being taught at the beginning of the course and, were only recently included.

Upon analysing the responses, it was noted that in Peruvian and Colombian institutions, the disciplinary approach combines both theoretical and practical application. In the Brazilian institution, there is a singular theoretical focus. However, there are several practical institutional projects and the teaching plan shows that there are field trips connected with it. Generally, outreach efforts to the community stands out. These range from collecting and donating surplus food, to course provision in urban agriculture. Other topics covered are: energy efficiency and management of solid waste resources. These activities have the capacity to expand the range of formal HEI subjects and enhance teaching pertaining to sustainability. National policy affecting a ban on disposable plates, the move towards smart buildings and utilities (e.g., affecting water usage) are also likely to support more academia/ cross sector linkages.

As far as the teaching content is concerned, attention to the triple bottom line of economic, social and environmental perspectives was represented in some way, in all of the institutions.

We then asked if the selection of the lecturer for the sustainability course required any special professional competencies and profile, everyone confirmed an expectation that these individuals would have knowledge and aptitude in the area. With regard to the Colombia institution, s/he should have sustainability qualification at the Master's level. It was noteworthy that the Brazilian institution responded that not only knowledge was important. What was also expected was, ". . . behave according to sustainable principles, since the example is fundamental for the student's learning". This is very significant as it underscores the importance of the teacher's expressed attitude towards the subject which is actually being taught.

Almost at the end of the interview (the penultimate question), the issue was raised about whether implementing the SD triple bottom line should be emphasized in the programs. The Brazilian interviewee agreed that these three dimensions are important and were discussed in 
the course. As for the Peruvian institution, one respondent leaned heavily towards the economic perspective, while also highlighting the social component of SD. The justification here was that the course's function was essentially business application. The interviewee representing Colombia did not directly address the issue, responding only to enquiry about the SDGs. One question was to determine course correlation to the SDGs. In this case, all the respondents confirmed the UN goals' relevance to their courses. The Brazilian respondent also stated that other disciplines were linked to the SDGs, while the respondent from Colombia informed that in their organizational context: “...the greater emphasis is given to strategic managerial decisions for sustainability".

Finally, respondents were asked their opinion about the need to study this discipline within the business curriculum. Based on their responses, it was apparent they believed that the investment would equip future Latin American students (at least from these three countries) as business professionals from emerging economies. Additionally, knowledge of SD principles will be a distinctive for any future business organization. One reason for this is that nowadays, customers and the general public are more aware of sustainability issues and are therefore more selective about their purchases and where they shop (Calzada, 2018; Harrison et al., 2005).

\section{Conclusions, Recommendations and Further Research}

In Brazil, Colombia and Peru, despite the PMRE set up by the UN, the attempts at research initiatives, projects and other academic engagements, much remains to be done about business programs in HEIs. We have reviewed a sample of sustainability and the sustainable development-related business programs of three Latin-American universities. There is a definite academic interest in sustainable development issues. From the literature review conducted, we found that ESD in HEI has a prominent role to play in the education of citizens, to prepare them to transform, influence and contribute to society. Therefore, ESD must support learning as a transdisciplinary discipline to allow graduates to take informed, conscientious and practical decisions as business professionals. This is based on the potential economic, social and environmental impact and, on society as a whole.

ESD provision in the three Latin American HEIs in this study, has made some basic inroads. Yet, overall, this activity still seems disparate. The review suggests that these institutions are endeavouring to provide students with required competencies by introducing SD across the 
business curriculum. It is also clear that students are encouraged through these programs to be agents of change. At the same time, since the concept of sustainable development is still perceived as sophisticated, this has raised expectations of students, companies and the wider society. There is a lack of comprehensive, strategic intent at an institutional level and this is resulting in some gaps in SD teaching delivery.

All the HEIs interviewed have specific subjects that deal with sustainability. Most of them addressed it at the end of the courses, by teachers who have a practical understanding of the concept. Although these faculty members may be free to insert content, they must follow the main program axis. Practical content is a teaching and learning essential. In so doing, business school staff are committed to shaping future managerial leadership that will impact their companies and contexts by astute decision making.

In the three universities studied, the course titles seem to clearly vouch for 'Sustainable development' and 'Social responsibility'. Both terms are closely linked to business but it is clear that the greatest weight of the HEI program content falls on the economic dimension of ESD. This is due to the very nature of a career in Business Administration. The social dimension is still noted and (to a lesser extent), environmental management is also being addressed. This imbalance needs to be corrected to improve the ESD efforts of these universities, especially because of their home countries' wider profiling as emerging economies.

\section{Recommendations \& Areas for Improvement}

The following critical action areas may help HEI in Latin America to improve ESD provision:

- Include more units related to innovation for sustainability in the curriculum. However, in laying out key concepts, these units should also cater to their practical application. This would be attractive to students seeking graduate business training.

- Use ESD as a launching pad to encourage research and learning surrounding business and community resilience. There is opportunity here for extension and outreach to NGOs, village councils and other civic organisations- helping to articulate solutions to real problems. This approach is especially now relevant in a Post-Covid environment.

- Address the uneven lopsided approach to teaching business education based on the traditional economic stance. HEIs should embrace opportunity for a more integrated 
teaching and learning matrix. This approach would acknowledge the environmental and social dimensions affecting everyday commerce and business.

- Promote the achievement of SDGs by creating networks of universities to share experiences and research about how to improve ESD impact, at teaching and research levels. In postCovid 19 times, prompting and identifying students, lecturers and administrative staff will impact the ways communities associated to the universities will cope better in postpandemic plans.

- The paper aims to survey the state of ESD in three HEIs in LA. We surveyed some of the curricula and interview programme leaders and the picture that emerged is a type of confusion and delay compared to other regions (particularly the US and EU). The problem we encounter is that these HEIs still have not developed enough work to distinguish between "sustainable development", "sustainability", and "sustainability literacy" perspective. Understanding these concepts is crucial to develop robust curriculum with useful ESD messaging. This cannot be done overnight. A crucial recommendation will be for the three universities to keep close contact with the Latin American networks reported here but also to get involved with Inter-University Sustainable Development Research Programme. (IUSDRP).

- It seems that in business related programmes, the role of teaching units related to corporate social responsibility (CSR) is still associated with topics such as sustainability and environmental development but is not research or appropriate reflection to link these concepts with ESD. Hence, there appears to be some confusion between the terms of what is understood by corporate social responsibility (CSR), amongst business studies programmes leaders. As it reported here, programme leaders in one of the universities in Peru emphasise the teaching of CSR in their curriculum as a way of introducing Education for Sustainability. The above confusion and lack of linkage between CSR units and, its potential as a vehicle to embed ESD, indicates that there is an urgency to abandon this emphasis on CSR with its economic paradigm. Instead there is a need to embrace the tasks of literacy sustainability across the curriculum in the three HEIs surveyed here. The aim should be the teaching of sustainability, as an integrated, complex whole (incorporating elements of environmental, social and economic sustainability). That said, we are also aware of the huge hurdles facing LA universities when a reform on the curriculum is suggested. 


\section{Limitations and further research}

Finally, the most obvious limitation of this Study is its small sample size as we only explored business courses in three Latin American universities. One cannot draw conclusions about how ESD is provided in the rest of the continent from such a small consortium. It should also be noted that the survey only entertained interviews with program leaders of business studies. Hence, we imagine that these findings are at least informative and, provide a base for further study. For example, the student viewpoint would significantly complement research of this kind. Additionally, getting input from HEI graduates that are already working in business could lead to valuable instruction for HEI and, value added, regarding curriculum re-design. There is also potential to use such alumni relationships to encourage more academia/ industry partnerships; for applying sustainability plans concerning green enterprise and, for related training curricula.

\section{Acknowledgements}

This research was carried out as part of the Manchester Metropolitan University Grant: QR

Global Challenges Research Fund 2018: Project: Enhancing Research on Sustainability and Resilience in marginalised communities in Latin America.

The authors are grateful to the valuable comments of the three reviewers of the initial manuscript; their comments have allowed us to greatly improve this article. We are also grateful to the business programme leaders of the three universities who kindly accepted to be interviewedmany thanks for your time and patience.

\section{References}

Acosta Castellanos, P.M., Queiruga Dios, A., Gomez Araque, L. and Rojas Ramos, P. (2020), "The Evolution from the Environmental Education Model to the Education for Sustainable Development Model. Case Study of Environmental Engineering at Santo Tomas University, Colombia", ACM International Conference Proceeding Series, Association for Computing Machinery, pp. 105-113.

Albareda Tiana, S., Fernández Morilla, M., Maria Mallarach Carrera, J. and Vidal Ramèntol, S. (2017), Barreras Para La Sostenibilidad Integral En La Universidad, Revista Iberoamericana de Educación, Vol. 73. 
Alves, N.B. (2017), "De onde vem esse currículo? A Educação Sustentável nos cursos de Administração".

Atherton, M. (2019), "Part 1: Behaviour change towards a circular economy | The Great Recovery", available at: http://www.greatrecovery.org.uk/resources/behaviour-changetowards-a-circular-economy-part-1/ (accessed 27 February 2021).

Australia/Pacifi, S. (2017), “Cómo empezar con los ODS en las universidades. Una guía para las universidades, los centros de educación superior y el sector académico", Sustainable Development Solutions Network, p. 56.

Becker, J. and Smith, D.. (2018), “The Need for Cross-Sector Collaboration: Addressing today's most pressing challenges requires developing the capacity to lead collaboratively and to effectively work across sectors", Stanford Social Innovation Review, available at: https://ssir.org/articles/entry/the_need_for_cross_sector_collaboration (accessed 26 February 2021).

Blanco-Portela, N., R-Pertierra, L., Benayas, J. and Lozano, R. (2018), “Sustainability leaders' perceptions on the drivers for and the barriers to the integration of sustainability in Latin American Higher Education Institutions", Sustainability (Switzerland), Vol. 10 No. 8, available at:https://doi.org/10.3390/su10082954.

Brandli, L.L., Filho, W.L., Frandoloso, M.A.L., Korf, E.Pa. and Daris, D. (2015), “The Environmental Sustainability of Brazilian Universities: Barriers and Pre-conditions”, Integrating Sustainability Thinking in Science Ans Engineering, World Sust., Springer International Publishing Switzerland, Switzerland, pp. 63-74.

Bronzeri, M. de S. and Cunha, J.C. da. (2020), "Ensino e prática para a sustentabilidade em IES: estudo de caso / Education and practice for sustainability in HEI: case study", Brazilian Journal of Business, Brazilian Journal of Business, Vol. 2 No. 4, pp. 34353450 .

Bugallo-Rodríguez, A. and Vega-Marcote, P. (2020), "Circular economy, sustainability and teacher training in a higher education institution", International Journal of Sustainability in Higher Education, Vol. 21 No. 7, pp. 1351-1366.

Calzada, I. (2018), “(Smart) Citizens from Data Providers to Decision-Makers? The Case Study of Barcelona", available at:https://doi.org/10.3390/su10093252.

CEPAL. (2016), "Desarrollo Social Inclusivo, una nueva generación de políticas para superar la pobreza y reducir la desigualdad en América Latina y Caribe”, Cepal, p. 304. Colurcio, M. and Russo-Spena, T. (2013), "Collaborative Innovation-A Focus on Food SMES", available at:https://doi.org/10.5772/54616. 
Consorcio de Universidades. (2016), “Objetivos de Desarrollo Sostenible | Consorcio de Universidades", available at: http://www.consorcio.edu.pe/objetivos-de-desarrollosostenible/ (accessed 1 February 2021).

Elkington, J. (1999), Cannibals with Forks: The Triple Bottom Line of 21st Century Business, edited by Capstone.

Ernst \& Young Global. (2015), ¿Cómo Pueden Contribuir Las Empresas a Los Objetivos de Desarrollo Sostenible? Breve Guía Para El Diseño, Ejecución y Reporte de Las Actividades, Mediante La Implementación Del SDG Compass, available at: http://www.ey.com/Publication/vwLUAssets/ey-como-pueden-contribuir-las-empresasa-los-objetivos-de-desarrollo-sostenible/\$FILE/ey-como-pueden-contribuir-lasempresas-a-los-objetivos-de-desarrollo-sostenible.pdf.

Fernandez, D. (2020), “EL AMBICIOSO PACTO VERDE EUROPEO* THE”, Actualidad Jurídica Ambiental, Vol. 101, pp. 78-109.

Flórez-Yepes, G.Y. (2015), "La educación ambiental y el desarrollo sostenible en el contexto colombiano", Revista Electrónica Educare, Universidad Nacional de Costa Rica, Vol. 19 No. 3, available at:https://doi.org/10.15359/ree.19-3.5.

Franco, I., Moura-Leite, R., Pereira, M.W.G. and De Jesus Lopes, J.C. (2017), "Personal values and approach of undergraduates towards corporate social responsibility", Social Responsibility Journal, Vol. 13 No. 3, pp. 457-472.

Fundación Aquae. (2013), “Agenda 2030: las 5P para transformar el mundo |", available at: https://www.fundacionaquae.org/agenda-2030-5p/ (accessed 3 June 2021).

García-González, E., Jiménez-Fontana, R., Azcárate Goded, P. and Cardeñoso, J.M. (2017), "Inclusion of Sustainability in University Classrooms Through Methodology", World Sustainability Series, Springer, pp. 3-19.

Godoy, A.S., Brunstein, J. and Fischer, T.M.D. (2013), "Introdução ao fórum temático sustentabiliade na s escolas de administração: Tensões e desafios", Revista de Administracao Mackenzie, Mackenzie Presbyterian University.

Gómez-Luna, E., Fernando-Navas, D., Aponte-Mayor, G., Luis, \& and Betancourt-Buitrago, A. (2014), "Literature review methodology for scientific and information management, through its structuring and systematization Metodología para la revisión bibliográfica y la gestión de información de temas científicos, a través de su estructuración y sistematizaci”, DYNA, Vol. 81 No. 184, pp. 158-163.

Harrison, R., Newholm, T. and Shaw, D. (2005), The Ethical Consumer, The Ethical Consumer, SAGE Publications Ltd, 1 Oliver's Yard, 55 City Road, London EC1Y 
1SP United Kingdom, available at:https://doi.org/10.4135/9781446211991.

Hernández-Diaz, P.M., Polanco, J.-A., Escobar-Sierra, M. and Filho, W.L. (2021), "Holistic integration of sustainability at universities: Evidences from Colombia", Journal of Cleaner Production, Vol. 305, p. 127145.

Hernandez, P.M., Vargas, V. and Paucar-Cáceres, A. (2018), “Education for sustainable development: an exploratory survey of a sample of latin american higher education institutions", World Sustainability Series, Springer, pp. 137-154.

Hidalgo, D.A., del Álamo, J.B. and Portela, N.B. (2020), Cómo Evaluar Los ODS En Las Universidades, Red Española para el Desarrollo Sostenible (REDS), Spain, available at: www.reds-sdsn.es/documentos (accessed 31 January 2021).

IAU. (2019), "Higher Education and Research for Sustainable Development”, International Association of Universities, available at: www.iauhesd.net $/+\& \mathrm{~cd}=13 \& \mathrm{hl}=\mathrm{es} \& \mathrm{ct}=\mathrm{clnk} \& \mathrm{gl}=\mathrm{co}($ accessed 19 February 2021).

Jacobi, P.R., Raufflet, E. and Arruda, M.P. de. (2011), “Educação para a sustentabilidade nos cursos de Administração: reflexão sobre paradigmas e práticas", RAM. Revista de Administração Mackenzie, Vol. 12 No. 3, pp. 21-50.

Kraaijenhagen, van Oppen, C. and Bocken, N. (2016), "NEW BOOK - 'CIRCULAR BUSINESS - COLLABORATE AND CIRCULATE' | Sustainable Business Model.org", available at: https://sustainablebusinessmodel.org/2016/03/31/new-bookcircular-business-collaborate-and-circulate/ (accessed 27 February 2021).

Leal Filho, W., Brandli, L.L., Becker, D., Skanavis, C., Kounani, A., Sardi, C., Papaioannidou, D., et al. (2018), "Sustainable development policies as indicators and pre-conditions for sustainability efforts at universities: Fact or fiction?", International Journal of Sustainability in Higher Education, Vol. 19 No. 1, pp. 85-113.

Lozano, R., Lukman, R., Lozano, F.J., Huisingh, D. and Lambrechts, W. (2013), "Declarations for sustainability in higher education: Becoming better leaders, through addressing the university system”, Journal of Cleaner Production, Vol. 48, Elsevier Ltd, pp. 10-19.

Malheiros, T.F.; et al. (2019), Universidades Rumo à Sustentabilidade, edited by SGA - USP, Sao Paulo, available at: http://www.profciambsaocarlos.eesc.usp.br/livro-paradownload-universidades-rumo-a-sustentabilidade/.

Minguet Aznar, P., U11, M.A., Piñero, A. and Martínez-Agut, M.P. (2014), “La Sostenibilidad En La Formación Universitaria: Desafíos Y Oportunidades”, Educación XX1, Vol. 17 No. 1, pp. 133-158. 
Panario, M. (2021), "El rol de las finanzas sostenibles en un nuevo capitalismo - Infobae", Infobae, Argentina, available at: https://www.infobae.com/opinion/2021/02/21/el-rol-delas-finanzas-sostenibles-en-un-nuevo-capitalismo/ (accessed 21 February 2021).

Petarnella, L., Silveira, A. and Machado, N.S. (2017), "Educação Ambiental e Ensino de Sustentabilidade: Reflexões no Contexto da Administração", Revista de Gestão Ambiental e Sustentabilidade, University Nove de Julho, Vol. 6 No. 1, pp. 1-12.

PMRE - Chapter Brazil. (2021), "Sobre o PMRE - Chapter Brazil”, available at: http://prmebrazil.com.br/mod/page/view.php?id=11 (accessed 7 February 2021).

PRME - Principles for Responsible Management Education. (2021a), "What is PRME?", available at: https://www.unprme.org/about\# (accessed 7 February 2021).

PRME - Principles for Responsible Management Education. (2021b), "PRME Signatories", available at: https://www.unprme.org/signatories (accessed 7 February 2021).

QAA. (2014), Education for Sustainable Development: Guidance for UK Higher Education Providers.

Ramirez-Sánchez, M., Rivas-Trujillo, E. and Cardona-Londoño, C. (2019), "El estudio de caso como estrategia metodológica The case study as a methodological strategy Contenido", Revista Espacios, Vol. 40 No. 23, p. 30.

REDS. (2020), Cómo Evaluar Los ODS En Las Universidades, available at: www.redssdsn.es/documentos (accessed 31 January 2021).

Rendón López, L.M., Londoño, J.V.E., Ruiz, Á.D.J.A., Benítez, J.A.M., Parodi, T.V. and Montaña, D.F.V. (2018), "Education for sustainable development: Approaches froma Colombian perspective", Produccion y Limpia, Vol. 13 No. 2, pp. 133-149.

Rojas, Ó.A.V. and Pineda, A.A.L. (2016), De La Educación Ambiental Hacia La Configuración de Redes de Sostenibilidad En Colombia, Perfiles Educativos |, Vol. XXXVIII.

Dela Rosa, Daniel; Giménez, Pilar; De la Calle, C. (2018), “LA SOCIEDAD DEL APRENDIZAJE: RETOS EDUCATIVOS EN LA SOCIEDAD Y CULTURA POSMODERNA", Revista Prisma Social, Vol. 25, p. 182.

Salvia, A. and Brandli, L. (2021), "Brazil”, in McCowan, T., Filho, W.L. and Brandli, L. (Eds.), Universities Facing Climate Change and Sustainability, Global Uni., KörberStiftung, Hamburg, pp. 54-61.

Segundo Castillo-Cabeza, M.N., Luis Canchingre-Bone, M.A. and Walter Becerra-Quiñonez, M. V. (2016), Reflexiones Sobre La Universidad y La Sociedad. Reflections on the University and Society Reflexões Sobre a Universidade Ea Sociedade, Vol. 2, available 
at: http://dominiodelasciencias.com/ojs/index.php/es/indexComunicacióncorta (accessed 31 January 2021).

Shephard, K. (2008), "Higher education for sustainability: Seeking affective learning outcomes", International Journal of Sustainability in Higher Education, Emerald Group Publishing Limited, Vol. 9 No. 1, pp. 87-98.

UNESCO. (1997), "Educating for a Sustainable Future : a Transdisciplinary”, No. November, p. 14.

UNESCO. (2017), "La UNESCO y los Objetivos de Desarrollo Sostenible”, available at: https://es.unesco.org/sdgs (accessed 16 February 2021).

United Nations. (2019), “United Nations Sustainable Development, Agenda 21: chapter 36”, available at: https://www.un.org/french/ga/special/sids/agenda21/action36.htm (accessed 16 February 2021).

United Nations. (2021a), “The Sustainable Development Goals: Our Framework for COVID19 Recovery - United Nations Sustainable Development”, Sustainable Development Goals, available at: https://www.un.org/sustainabledevelopment/sdgs-framework-forcovid-19-recovery/ (accessed 22 February 2021).

United Nations. (2021b), Take Action for the Sustainable Development Goals, Ammersfoort:The Netherlands.

Universia. (2019), “Universidades sostenibles: situación actual en el Perú”, Universia, available at: https://www.universia.net/pe/actualidad/orientacionacademica/universidades-sostenibles-situacion-actual-peru-1166422.html (accessed 1 February 2021).

Vargas, V.R., Lawthom, R., Prowse, A., Randles, S. and Tzoulas, K. (2019), "Implications of vertical policy integration for sustainable development implementation in higher education institutions”, Journal of Cleaner Production, Elsevier Ltd, Vol. 235, pp. 733 740 .

Van de Ven, A.H. (2007), Engaged Scholarship: A Guide for Organizational and Social Research, Oxford University Press, Oxford.

Weissman, N.B. (2012), "Sustainability \& Liberal Education: Partners by Nature", Liberal Education, Vol. 98 No. 4.

Yamamoto, V.S., Moura-Leite, R., Machado, N.S. and Freitas, W.R. de S. (2020), "Sustentabilidade no Ensino: Um Diagnóstico dos Cursos de Administração da Universidade Federal de Mato Grosso do Sul”, Revista FSA, Revista FSA, Vol. 17 No. 3, pp. 127-149. 


\section{Appendix 1 \\ Mission and Provision of Subjects in Business Programs of Universities of Brazil, Peru and Colombia}

\section{BRAZILIAN UNIVERSITY}

Mission of the University: To build and disseminate knowledge, contributing to the formation of human beings, so that they can exercise their role in society with ethics and citizenship

Mission of the Business Academic Program: The Business Administration course takes students to learn about the transformations that have been occurring in the Administration area, in industries, in commerce, in the service sector and Educational Institutions, with its focus mainly on the aspects of sustainability and social responsibility.

\section{THEMES OF THE BUSINESS PROGRAMME (BUSINESS ADMINISTRATION)}

Strategic Management for Sustainability

\section{TOPICS IN THE SUBJECT OF SUSTAINABILITY SUSTAINABLE DEVELOPMENT}

Strategic management for sustainability, Sustainable development, Environmental management: concepts and perspectives, Social responsibility, Sustainability indicators, Sustainable management audit instruments, Historical evolution of the environmental issue: Environment and Development, Agenda 21, Eco92, Kyoto Protocol , Earth Charter, Agenda 2030, Global and regional environmental management, Environmental public policies, Business environmental management, Environmental management system, Environmental impact study.

\section{ACTIVITIES PROMOTING SUSTAINABILITY}

1994-2021: Solidarity Action: Community-oriented actions with the purpose of integrating freshmen and veterans. Collection and subsequent donation of food for the neediest, supplements for people with cancer, blood donation and other solidarity actions. 2011 - 2021: Weeks with conferences and actions, week of conferences and practical actions that involve all degree courses. Community-oriented actions. 2018 - 2021 : Ecological and Social Responsibility Project - at the university practically working on SDG 12 "Responsible Consumption and Production" and 15 "Life on Earth". 2004-2021: And many other communities oriented Social Projects. 


\section{PERUVIAN UNIVERSITY}

Mission of the University: Provide humanistic, scientific and technological professional training to university students with quality and social responsibility.

Mission of the Business academic Programme: To train competitive professionals in administration, with ethical, proactive and entrepreneurial principles and values, prepared to create, innovate and manage organizations, capable of adapting to changing trends in the environment. We are a professional school that trains commercial engineers in the practice of competitiveness, with an innovative and entrepreneurial mentality, with the support of qualified students and teachers with professional experience and specialization, as well as the use of ICTs for each learning process. Promote a new type of commercial engineer with a business profile, global and with values of social responsibility.

\section{THEMES OF THE BUSINESS PROGRAMMES}

(1) Administrative Sciences: Social responsibility. (2) Business Engineering: Sustainable development and social responsibility, Management of social projects

\section{TOPICS IN THE SUBJECT OF SUSTAINABILITY SUSTAINABLE DEVELOPMENT}

Administrative Sciences: Foundations of CSR, management of CSR. Environmental Management, Communicate CSR. Doctrinal aspects of ethics and morals, ethics and business - strategies, perspectives. Commercial Engineering: -Sustainable development and social responsibility, Socio-environmental Policies and Regulation. Social strategies for sustainable development. Environmental economics. Design and Evaluation of sustainable projects. CSR. -Management of social projects: Introduction to Social Management: Social Policy / Management, SDGs, Social Programs, Budgetary Programs, evaluation of social programs, Indicators Bases of, Ex post evaluations of investment projects.

\section{ACTIVITIES PROMOTING SUSTAINABILITY}

Implementation in the last five years of the management of Social Responsibility, development of activities in the different areas of Extension and Cultural Projection, Basadrino Volunteer Programs and Links with Interest Groups, University Extension, Social Projection and Social Service and Coordination Area of the RSU for Research and Continuous Training. Participation in forums and implementation of Risk and Disaster Management. Integration in URSULA Networks (Union of Latin American University Social Responsibility). Participation of the university community in Environment Week, in social projects for the community, and in research on solar energy projects. Implementation of infrastructure projects with solar energy. Implementation of rules for the proper use of water and no entry of technopor utensils. 


\section{COLOMBIAN UNIVERSITY}

Mission of the University: Teaching and Social Sciences research, with a humanistic conception, the Externado de Colombia University promotes and practices absolute respect for life. The Externado's endeavour is developed within a pluralistic philosophy, open to all currents of thought, alien to dogmatism and respectful of all religious creeds and political ideologies. The University promotes tolerance as a formula to achieve peace and progress within heterogeneity, welcomes students from all regions of the country, and considers diversity as one of its greatest assets.

Mission of the Business academic Programme: We train agents of change in management skills to qualify the contribution that organizations make to sustainable development in emerging economies

\section{THEMES OF THE BUSINESS PROGRAMME OF BUSINESS ADMINISTRATION}

Sustainable development, Production of goods and services, Social Responsibility

\section{TOPICS IN THE SUBJECT OF SUSTAINABILITY SUSTAINABLE DEVELOPMENT}

Production, Social inclusion, 3R, Production, Environmental Services, Global pact, Sustainable development, Theories of sustainability, Productive processes, Green management, Fair trade, bio economy, Green business.

\section{ACTIVITIES PROMOTING SUSTAINABILITY}

The university is part of the Global Compact; develop different actions in the frame of Corporate Social Responsibility among the community and the neighbourhood.

It offers free academic programs to the residents of the campus of the Egypt neighbourhood community, such as urban agriculture, gardens and clean production among others. It works in a program about solid Waste Management inside the campus. Has mixed Restrooms, Gardens and Green Paths, Parking Rate According to Number of Occupants, Solar Energy Project, Smart and Efficient Buildings in 52\% of the Campus. 


\title{
Appendix 2 \\ Interviews: Responses from Business programs leaders
}

\author{
Question 1. Since when are you responsible for Business program? \\ Brazilian: I started as Head of the Business Department in December 2017.
}

Peruvian: 5 months and 2 months both with experience in other management positions within the program

Colombian: Since 2007, it began with the Sustainable Development chair for all programs

Question 2. What is (are) the name (or the names) of the course subject (s) that deal with sustainability?

Brazilian: Strategic Management for Sustainability

Peruvian: In one school: Sustainable development and social responsibility, Management of social projects and with the previous curriculum (2014) curricular: Ethics and social responsibility (elective course) In the other school Social Responsibility

Colombian: Sustainable development, Production of goods and services, Social Responsibility

Question 3. In which semester or period (s) is it taught?

Brazilian: Currently, in the $3^{\text {rd }}$. semester $\left(2^{\text {nd }}\right.$.year), but with the alteration of the curricular grade starting in 2021 , the discipline will be taught in the $8^{\text {th }}$. Semester of the course ( $4^{\text {th }}$ year).

Peruvian: 8th, 10th and 7th (of the 2014 mesh) and in the other school it was taught in the first semester

Colombian: 7th semester undergraduate. Fundamental modules of all undergraduates

\section{Question 4. Since when the course entered into the curriculum?}

Brazilian: The discipline existed in the Business curriculum for more than one decade, but previously, it was called "Management and Sustainable Development".

Peruvian: One school states that these courses related to Sustainable Development have always been taught in the other manifest school since 2018.

Colombian: Since 2007 in postgraduate and 1999 in undergraduate with Environmental Management that has been changing its name and today Sustainable Development

Question 5. Is it a theoretical or applied discipline? If applied, what is the application mode? Could you mention some projects or actions developed?

Brazilian: In the Business course, it is a theoretical discipline, but the Institution develops some practical projects related to sustainability: reduction (or elimination) of the use of disposable cups, separation of garbage, awareness to reduce waste of water, energy, Green Week, etc.

Peruvian: In both schools, the courses are theoretical. Practical. They refer that they develop projects towards the community characterized to mitigate the impact on the economy, society, such as through the value chain or other indicators. 
Colombian: I could cite some projects or actions that they have developed. Conceptual theorists who must then use their principles in all subjects. It is a way of thinking to make the performance of the career or postgraduate sustainable from there.

Question 6. What are the topics covered in class?

Brazilian: Strategic Management for Sustainability, Sustainable development, Environmental Management: concepts and perspectives, Social responsibility, Sustainability Indicators, Sustainable Management Audit Instruments, Historical evolution of the environmental issue: Environment and Development, Agenda 21, Eco92, Kyoto Protocol, Earth Charter, Agenda 2030, Global and Regional Environmental Management, Environmental Public Policies, Business Environmental Management, Environmental management system, Environmental impact study.

Peruvian: In a school, it deals with economics, social impact, and the environment. UNIT I: Fundamentals of CSR, management of CSR.

In the other school, the course on social responsibility addresses. UNIT II: Environmental Management, Communicate CSR.

UNIT III: Doctrinal aspects of ethics and morals, ethics and business - strategies, perspectives. Subject competences:

- Understands social responsibility as a dimension of a socially responsible company.

- Relates different processes of sustainable development.

- Identify ethical values in the development of your professional training as a business administrator

Colombian: Environmental crisis, Social crisis, Solutions from microeconomics (business), Macroeconomic solutions (structural), Capitalism and ethical dilemmas.

\section{Question 7. Does the selection of the professor for the sustainability course imply in any profile?}

Brazilian: The professor who teaches the discipline related to sustainability needs to fill in the necessary knowledge related to the theme and behave according to sustainable principles, since the example is fundamental for the student's learning. In any case, other disciplines and other professors who also approach the sustainability topic, behave, in their daily lives, according to sustainable principles.

Peruvian: In one school, they mention that they try to make the professor aligned with the profile, allowing these courses to be taught. In the other case, professor of the School of Education with knowledge of Social Responsibility teach

Colombian: Training in sustainability issues at the master's level.

Question 8. Is there any thematic axis that the professor should follow or is he totally free to insert themes, references and teaching methodology?

Brazilian: At our Institution, all professors are free to insert themes, references and teaching methodologies, as long as they are in line with the National Curricular Guidelines of the course.

Peruvian: There is a thematic axis inserted in the unit summary, in one it says sustainable development and Social Responsibility, Even marketing, the social responsibility of marketing. If any point is touched within the course, they have that profile and validate the competence. The other school specifies that it is free 
Colombian: Free within the framework of the topics of question 6

Question 9. Of the three dimensions that sustainable development implies: economic, social and environmental, do you consider that any have received more emphasis on their development and implementation in the course? Is the link with the SDGs (UN Sustainable Development Goals) studied?

Brazilian: I believe that the three dimensions should walk side-by-side, without any preference for their development and implementation. In the case of the SDGs, there is the study, not only in the discipline of Strategic Management for Sustainability, but also as a complement in several subjects of the course.

Peruvian: In a school, they obviously need the economic one due to the nature of the career and the social component is very strong. Consider that the issue is not an environmental course is the most. In the other case, it must necessarily link with the purpose of complying with the sustainable development of the production, transformation and commercial process.

Colombian: The SDGs and their rationale and implications are studied. Greater emphasis is given to strategic managerial decisions for sustainability

Question 10. In your opinion, why does the Administrator need to study this discipline within the curriculum?

Brazilian: The study and knowledge of the discipline related to sustainability are fundamental for the success of any Administrator, mainly due to the atypical moment lived by humanity. In addition, acting according to sustainable principles becomes a great differential for any organization. Currently, it is essential for any serious organization that wants to stand out adopt sustainable principles. Another important aspect is the organization and the manager image before the public. Nowadays, the public is more selective, more attentive to the sustainable issue and much more selective about the relationships established with organizations; those relations that conform to sustainable principles have great market appeal.

Peruvian: A school states that not only study ODS but also study aligned with the Bicentennial Plan, Regional Plan and the institutions close gaps, not everything is economic, you must think about equity and social work emphasized to education and social are the important challenges. Professionals must have this immersed in order to maintain the planet, generate awareness about it, contribute to that change. The other school states that business development includes the ethical process in production, transformation and marketing, to protect the environment.

Colombian: We include it in the mission of the faculty since 2016. It is our mission. Mission: We train agents of change in management skills to qualify the contribution that organizations make to sustainable development in emerging economies 


\section{Appendix 3}

Template to collect information to ascertain ESD development in Business programmes in three $L A$ universities

\section{1.-CONSOLIDADO DE IMPLEMENTACIÓN DE CURSO DE DESARROLLO SOSTENIBLE}

\begin{tabular}{|c|c|c|c|c|c|c|c|c|c|c|}
\hline \multirow[b]{2}{*}{ PAÍS } & \multirow[b]{2}{*}{$\begin{array}{c}\text { Nombre de } \\
\text { la } \\
\text { Universidad }\end{array}$} & \multirow[b]{2}{*}{ Condición } & \multirow[b]{2}{*}{$\begin{array}{c}\text { Denominación } \\
\text { de Programas } \\
\text { pregrado }\end{array}$} & \multirow[b]{2}{*}{$\begin{array}{c}N^{\circ} \text { total } \\
\text { de } \\
\text { Cursos } \\
\text { de } \\
\text { E.D.S }\end{array}$} & \multicolumn{6}{|c|}{ Especificaciones de Cursos de E.D.S } \\
\hline & & & & & Nombre & $\begin{array}{l}\text { Área } \\
\text { 1.General } \\
\text { 2. } \\
\text { Especialidad }\end{array}$ & Semestre & Créditos & HT & HP \\
\hline \multicolumn{11}{|l|}{ BRASIL } \\
\hline \multicolumn{11}{|l|}{ PERÚ } \\
\hline COLOMBIA & & & & & & & & & & \\
\hline
\end{tabular}

Leyenda:

$\begin{array}{ll}\text { E.D.S } & \text { Educación de Desarrollo Sostenible } \\ \text { HT } & \text { Horas teoría } \\ \text { HP } & \text { Horas Práctica }\end{array}$

\section{2.- TEMAS DE CURSO DE EDUCACIÓN DE DESARROLLO SOSTENIBLE}

\begin{tabular}{|l|c|c|c|c|c|}
\hline \multirow{2}{*}{\multicolumn{1}{c|}{}} & & & \multicolumn{2}{|c|}{ DIMENSIÓN } \\
\cline { 5 - 6 } \multicolumn{1}{c|}{ PAÍS } & $\begin{array}{c}\text { Integra en su Misión } \\
\text { del Programa de } \\
\text { estudio EDS }\end{array}$ & $\begin{array}{c}\text { Nombre } \\
\text { de curso } \\
\text { de EDS }\end{array}$ & $\begin{array}{c}\text { Económico } \\
\text { (temas) }\end{array}$ & $\begin{array}{c}\text { Social } \\
\text { (temas) }\end{array}$ & $\begin{array}{c}\text { Medio ambiental } \\
\text { (temas) }\end{array}$ \\
\hline BRASIL & & & & & \\
\hline PERÚ & & & & & \\
\hline COLOMBIA & & & & & \\
\hline
\end{tabular}

